\title{
Leukotriene B4 Measurement
}

National Cancer Institute

\section{Source}

National Cancer Institute. Leukotriene B4 Measurement. NCI Thesaurus. Code C103413.

The determination of the amount of the leukotriene B4 in a sample. 